\title{
Age Dependence of the Levels of Plasma Norepinephrine, Aldosterone, Renin Activity and Urinary Vanillylmandelic Acid in Normal and Essential Hypertensives
}

\author{
NADIA M. ABD-ALLAH ${ }^{1}$, FAYEZA H. HASSAN ${ }^{2}$, AMR Y. ESMAT $^{1}$ and \\ SOMAYA A. HAMMAD ${ }^{2}$ \\ ${ }^{1}$ Dept. of Biochemistry, Faculty of Science, Ain Shams University, Cairo, Egypt. \\ ${ }^{2}$ Dept. of Clinical and Chemical Pathology, Faculty of Medicine, Diabetic,Endocrine and Metabolic Pediatric \\ Unit of Children New Hospital, Cairo University, Egypt.
}

\begin{abstract}
In the present study the upper reference limits (URLs) for resting plasma norepinephrine, epinephrine, serum aldosterone, plasma renin activity, aldosterone/ renin activity ratio, as well as urinary vanillylmandelic acid in healthy Egyptian normotensive subjects over a range of ages (5-60 yr) were established. There was a significant age effect on plasma norepinephrine, UVMA, serum aldosterone and PRA, whereas a single URL for plasma epinephrine level is satisfactory. In uncomplicated untreated essential hypertensive subjects (5-60 $\mathrm{yr}$ ), the average prevalence of elevation in the plasma norepinephrine, epinephrine and urinary vanillylmandelic acid above their corresponding URLs was $85.10,62.15$ and $83.20 \%$, respectively. This suggests that elevation in plasma catecholamine concentrations is more likely a common consequence than playing a possible role in the pathogenesis of hypertension, supported by insignificant correlation coefficients between the plasma catecholamine levels and resting systolic and diastolic blood pressure values (SBP\&DBP) in all hypertensive age groups. Primary hyperaldosteronism was not detected among the normokalemic essential hypertensives at any age using aldosterone /plasma renin activity ratio as a primary screening method. In the present study, 7 statistically significant positive coefficient correlations are reported for SBP or DBP values with UVMA levels in hypertensive children and adolescents, serum aldosterone in old hypertensives, and PRA in adult hypertensives.
\end{abstract}

\section{INTRODUCTION}

Essential hypertension refers to the $90-95 \%$ of cases of hypertension in which the cause is unknown. It is characterized by a steady increase in blood pressure, which is a major risk factor for heart disease and stroke (Braun et al., 1994). The catecholamines which are produced by the adrenal medulla are involved in a number of neuropsychiatric disorders and hypertension. The literature contains a conflict about the possible role of plasma catecholamines in the pathogenesis of hyertension (Ribeiro et al., 1992 and Dosch, 2001) or as a common consequence (Jablonskis and Howe, 1995 and Jacobs et al., 1997). Also, much of the published normal reference ranges for plasma free catecholamines in healthy children are incomplete and often contradictory in normotensive adults. Measurement of plasma free catecholamines and their urinary metabolite (VMA) are very important in the diagnosis of some diseases, such as phaechromocytoma, which is potentially lethal if undetected (Smythe et al., 1992). The variations in catecholamine assay methodologies and the recent improvements point out the need for establishing reference values among different age and ethnic groups so that abnormal results could be interpreted appropriately.

Formerly screening for primary hyperaldosteronism (Conn's syndrome) was often reserved for hypertensive subjects with hypokalemia. A new familial variety with aldosterone producing adenomas 
(some responsive and some unresponsive to angiotensin II), or bilateral hyperplasia not suppressible with glucocorticoids was described (Gordon et al.,1991, 1992 and 1995). This led to a return to Conn's original observation that this set of conditions occurs with normal serum potassium (Mckenna et al.,1991), and a further improved sensitivity of diagnosis by use of the plasma aldosterone/ renin activity ratio as a primary screening method (Hiramatsu et al., 1981 and Gordon, 1993). Gordon et al. (1994) proposed an incidence of $5-15 \%$ for primary hyperaldosteronism in those who would otherwise be labelled "essential hypertensives".

This pilot study was undertaken to establish the reference values of plasma norepinephrine, epinephrine, urinary vanillylmandelic acid, serum aldosterone and plasma renin activity (PRA) levels in Egyptian healthy normotensive subjects at different ages (5-60 years). The aim of this study is also extended to study the roles of plasma catecholamines in the pathogenesis of essential hypertension and to screen for the prevalence of primary hyperaldosteronism among Egyptian hypertensives at all ages.

\section{SUBJECTS, MATERIALS AND METHODS}

\section{Cases}

The present study was conducted on 101 nonsmoking subjects of both sexes (57 females and 44 males) aged 5-60 years with mild to severe uncomplicated untreated essential hypertension (resting SBP 142-156 $\mathrm{mmHg}$ and DBP 93-100 $\mathrm{mmHg}$ ), who were chosen from the patients and their relatives attending Diabetic, Endocrine and Metabolic Pediatric Unit (DEMPU) of Children New Hospital, Cairo University. For statistical comparison 115 age-matched normotensive subjects (SBP/DBP 117 $\pm 3 / 77 \pm 3 \mathrm{mmHg}$ ) were taken as normal control groups. For normo-and hypertensive cases the exclusion criteria were: significant cardiac disease, such as angina pectoris, myocardial infarction, congestive heart disease, chronic dysrhythmias or conduction disturbances; peripheral vascular disease; pulmonary diseases; liver disease; alcohol or drug abuse; pregnancy; or other unstable clinical diseases, such as metastatic cancer, systemic infection and hypothyroidism. To emphasize that the chosen cases have no diabetes mellitus, significant kidney disease or hyperlipidaemia, determination of serum glucose, sodium, potassium, calcium, urea, creatinine, total cholesterol and triglycerides was carried out.

\section{Groups}

The chosen cases were classified according to the following scheme: Gr.Ia: Normal children (5-10 yr, $\mathrm{n}=25)$, Gr.IIa: Hypertensive children (5-10 yr, $n=25)$, Gr.Ib: Normal adolescents (11-15yr, $n=24)$, Gr.IIb: Hyertensive adolescents (11-15 yr, $\mathrm{n}=25)$, Gr.Ic: Normal adults (16-40 yr, $\mathrm{n}=41)$, Gr.IIc: Hypertensive adults (16-40 yr, $n=25)$, Gr.Id: Older subjects (40-60 yr, $\mathrm{n}=25)$ and Gr.IId: Older hypertensives (40$60 \mathrm{yr}, \mathrm{n}=26)$.

\section{Methods}

For each case, after a fast of $12 \mathrm{~h}$ and seated rest of $30 \mathrm{~min}$, the systolic and diastolic blood pressures were measured and then a volume of $10 \mathrm{ml}$ blood was drawn from the intravenous cannula. Each blood sample was divided into three tubes as follows: a heparin-EGTA tube which was placed in an ice bath for $10 \mathrm{~min}$, then centrifuged and the plasma promptly separated and stored at $20^{\circ} \mathrm{C}$ for determination of resting plasma catecholamines; a plain tube for serum preparation, for aldosterone determination and routine chemistry analysis; and a cold EDTA tube which was rapidly centrifuged and the plasma was stored at $-20^{\circ} \mathrm{C}$ for determination of plasma renin activity. Plasma norepinephrine (NE) and epinephrine (E) concentrations were measured after extraction by the radioimmunoassay (RIA) method using commercial assay kits (IBL, Germany, Cat. No: RE 29325). Serum aldosterone concentration was determined by the solid phase radioimmunoassay using a 
commercial kit (DPC-Diagnostic Products Co, U.S.A. Cat. No: TKAL1). Plasma rennin activity (PRA) was assessed through the generation of angiotensin I and measuring the latter by a solid phase RIA kit (Diasorin, USA, Cat. No: CA 1533). Urinary vanillylmandelic acid (VMA) concentration was estimated according to the method of Wybenga \& Pileggi (1967) using a commercial assay kit (Biomidi, France). Serum urea nitrogen, creatinine, electrolytes, total cholesterol, triglycerides and glucose were measured by the Synchrone CX5 autoanalyser (Beckman, USA).

\section{Statistical Analysis}

The statistical significance of the experimental results was determined by the Student's-t-test and the correlation coefficients (r-values) between the different studied parameters were calculated (Murray, 1982). For all analysis, $\mathrm{p}<0.05$ was accepted as a significant probability level.

\section{RESULTS}

Table 1. shows the effect of advancing age on resting plasma NE, E, serum aldosterone, PRA, Aldo/PRA ratio and UVMA levels in normal subjects, in comparison to the lowest control age group (5-10yr). In adolescents (11-15yr) serum aldosterone, PRA and UVMA recorded a statistically significant elevation of $26.31(\mathrm{P}<0.05), 25.80(\mathrm{P}<0.02)$ and $21.54 \%(\mathrm{P}<0.01)$, respectively, while plasma NE level showed a slight reduction of $15.8 \% \quad(\mathrm{P}<0.01)$. In young adults (1640yr) and older subjects (41-60yr) UVMA level was significantly increased by 47.07 and $64.36 \%(\mathrm{P}<0.001)$, respectively, while serum aldosterone, PRA, and NE levels were nonsignificantly changed. Levels of resting plasma E and Aldo/PRA ratio were also nonsignificantly changed by advancing age.

Table 2. demonstrates the upper reference limits (URLs) for plasma catecholamines, UVMA, serum aldosterone, PRA and Aldo/PRA ratio for controls in all age groups. Multiple comparisons between the URLs for each analyte in the different age groups revealed that the URLs for resting plasma $\mathrm{NE}$ and serum aldosterone levels were not different $(\mathrm{P}>0.05)$ in the age groups 5-10, 16-40 and 41-60 yr with an average of $362.4 \mathrm{pg} / \mathrm{ml}$ and $33.02 \mathrm{ng} / \mathrm{dl}$, respectively .In the normotensive adolescent group (11-15 yr) the URLs for plasma NE and serum aldosterone were 287 $\mathrm{pg} / \mathrm{ml}$ and $36.10 \mathrm{ng} / \mathrm{dl}$, respectively. The URLs for resting plasma $\mathrm{E}$ and Aldo/PRA ratio in the different control age groups were not significantly changed, averaging $137.18 \mathrm{pg} / \mathrm{ml}$ and 20, respectively, for all studied ages. The URL for UVMA was $4.05,6.33$ and 8.05 for normotensive children, adolescents and adults (16-60yr), respectively. Likewise, PRA showed three age-dependent URLs, which were $5.30 \mathrm{ng} /$ $\mathrm{ml} / \mathrm{h}$ for children and adults, $3.8 \mathrm{ng} / \mathrm{ml} / \mathrm{h}$ for adolescents and $6.10 \mathrm{ng} / \mathrm{ml} / \mathrm{h}$ for old subjects.

Table 3. illustrates the changes in the levels of plasma NE, E, UVMA, serum aldosterone, PRA and Aldo/PRA ratio in hypertensive subjects at all ages, compared to age-matched normotensives. Plasma NE and $\mathrm{E}$ levels were significantly changed in hypertension in an opposite manner. NE was significantly increased by $71.85 \%$ $(\mathrm{P}<0.001)$ in hypertensive children, while it reached its maximum value in adolescents and adults (144.70 and $145.53 \%, \mathrm{P}<0.001$, respectively), with a slightly lesser increase of $123.51 \% \quad(\mathrm{P}<0.001) \quad$ in older hypertensives. On the other hand, plasma $\mathrm{E}$ level was most elevated of 96.56 and $97.91 \%(\mathrm{P}<0.001)$ in hypertensive children and old adults, respectively, with a significantly less pronounced increases of 59.45 and $63.86 \%(\mathrm{P}<0.001)$ in adolescents and adults, respectively. UVMA concentrations significantly increased over the age range studied. The increase $\%$ was 109.34, 54.92, 80.29 and $59.55(\mathrm{P}<0.001)$ at ages 5-10, 11-15, 16-40, 41-60 yr., respectively. Serum aldosterone level was significantly increased by $53.29 \%$ $(\mathrm{P}<0.001)$ in children and then tended to decrease gradually with advancing age showing increases of $39.75(\mathrm{P}<0.001)$, $32.33(\mathrm{P}<0.01)$ and $25.71 \%(\mathrm{P}<0.001)$ in hypertensive cases aged 11-15, 16-40 and 41-60 yr, respectively. PRA was 


\section{TABLE I}

Statistical significance of advancing age on the levels of plasma norepinephrine, epinephrine, urinary vanillylmandelic acid, serum aldosterone, plasma renin activity and Aldo/PRA ratio in normotensive subjects at variable ages.

\begin{tabular}{|c|c|c|c|c|}
\hline Parameters & $\begin{array}{c}\text { Gr. Ia } \\
(5-10 \mathrm{yr})\end{array}$ & $\begin{array}{c}\text { Gr. Ib } \\
(11-15 y r)\end{array}$ & $\begin{array}{c}\text { Gr. Ic } \\
(16-40 y r)\end{array}$ & $\begin{array}{c}\text { Gr. Id } \\
(41-60 y r)\end{array}$ \\
\hline & $\mathrm{n}=25$ & $\mathrm{n}=24$ & $\mathrm{n}=41$ & $\mathrm{n}=25$ \\
\hline $\begin{array}{l}\text { SBP }(\mathrm{mmHg}) \\
\quad \text { Mean } \pm \text { S.D }\end{array}$ & $114.68 \pm 4.03$ & $116.04 \pm 3.89$ & $117.8 \pm 3.72$ & $120.40 \pm 4.98$ \\
\hline \multicolumn{5}{|l|}{ DBP (mmHg) } \\
\hline Mean \pm S.D & $74.20 \pm 4.0$ & $75.42 \pm 3.88$ & $76.95 \pm 4.01$ & $79.60 \pm 2.86$ \\
\hline \multicolumn{5}{|c|}{ Norepinephrine (pg/ml) } \\
\hline $\begin{array}{l}\text { Range } \\
\text { Mean } \pm \text { S.D }\end{array}$ & $\begin{array}{c}(150-320) \\
231.6 \pm 50.36\end{array}$ & $\begin{array}{l}(112-325) \\
195 \pm 45.97\end{array}$ & $\begin{array}{c}(112-350) \\
234.15 \pm 65.31\end{array}$ & $\begin{array}{c}(120-391) \\
252.92 \pm 68.4\end{array}$ \\
\hline $\begin{array}{l}\text { Change \% } \\
\mathrm{P}<\end{array}$ & $\begin{array}{l}- \\
-\end{array}$ & $\begin{array}{l}-15.8 \\
0.01\end{array}$ & $\begin{array}{l}1.10 \\
\text { N.S }\end{array}$ & $\begin{array}{r}9.2 \\
\text { N.S }\end{array}$ \\
\hline \multicolumn{5}{|c|}{ Epinephrine (pg/ml) } \\
\hline $\begin{array}{l}\text { Range } \\
\text { Mean } \pm \text { S.D }\end{array}$ & $\begin{array}{c}(59-130) \\
90.68 \pm 20.10\end{array}$ & $\begin{array}{c}(44-120) \\
93.17 \pm 17.98\end{array}$ & $\begin{array}{c}(16-183) \\
91.54 \pm 30.31\end{array}$ & $\begin{array}{c}(51-135) \\
91.28 \pm 22.56\end{array}$ \\
\hline $\begin{array}{l}\text { Change \% } \\
\mathrm{P}<\end{array}$ & $\begin{array}{l}- \\
-\end{array}$ & $\begin{array}{l}2.7 \\
\text { N.S }\end{array}$ & $\begin{array}{l}0.94 \\
\text { N.S }\end{array}$ & $\begin{array}{l}0.66 \\
\text { N.S }\end{array}$ \\
\hline \multicolumn{5}{|l|}{ UVMA (mg/24h) } \\
\hline $\begin{array}{l}\text { Range } \\
\text { Mean } \pm \text { S.D }\end{array}$ & $\begin{array}{c}(1.9-4.2) \\
3.76 \pm 1.13\end{array}$ & $\begin{array}{c}(3.5-6.1) \\
4.57 \pm 0.88\end{array}$ & $\begin{array}{c}(2.9-8.0) \\
5.53 \pm 1.17\end{array}$ & $\begin{array}{l}(4.9-8.1) \\
6.18 \pm 0.94\end{array}$ \\
\hline $\begin{array}{l}\text { Change \% } \\
\mathrm{P}<\end{array}$ & - & $\begin{array}{c}21.54 \\
0.01\end{array}$ & $\begin{array}{l}47.07 \\
0.001\end{array}$ & $\begin{array}{l}64.36 \\
0.001\end{array}$ \\
\hline \multicolumn{5}{|l|}{ Aldosterone(ng/dl) } \\
\hline $\begin{array}{l}\text { Range } \\
\text { Mean } \pm \text { S.D }\end{array}$ & $\begin{array}{c}(7.0-42.6) \\
18.23 \pm 7.31\end{array}$ & $\begin{array}{l}(14.2-34.0) \\
23.03 \pm 6.82\end{array}$ & $\begin{array}{c}(7.0-30.6) \\
19.54 \pm 6.06\end{array}$ & $\begin{array}{l}(11.2-32.1) \\
21.25 \pm 6.66\end{array}$ \\
\hline $\begin{array}{l}\text { Change } \% \\
\mathrm{P}<\end{array}$ & $\begin{array}{l}- \\
-\end{array}$ & $\begin{array}{c}26.31 \\
0.05\end{array}$ & $\begin{array}{l}7.18 \\
\text { N.S }\end{array}$ & $\begin{array}{l}16.56 \\
\text { N.S }\end{array}$ \\
\hline \multicolumn{5}{|l|}{ PRA (ng A1/ml/h.) } \\
\hline $\begin{array}{l}\text { Range } \\
\text { Mean } \pm \text { S.D }\end{array}$ & $\begin{array}{c}(1.2-3.9) \\
2.44 \pm 0.69\end{array}$ & $\begin{array}{c}(1.6-5.4) \\
3.07 \pm 1.07\end{array}$ & $\begin{array}{c}(0.5-5.1) \\
2.93 \pm 1.24\end{array}$ & $\begin{array}{c}(1.2-4.9) \\
2.86 \pm 0.96\end{array}$ \\
\hline $\begin{array}{l}\text { Change \% } \\
\mathrm{P}<\end{array}$ & - & $\begin{array}{l}25.8 \\
0.02\end{array}$ & $\begin{array}{l}20.1 \\
\text { N.S }\end{array}$ & $\begin{array}{l}17.2 \\
\text { N.S }\end{array}$ \\
\hline \multicolumn{5}{|c|}{ Aldo (ng/dl) / PRA (ng/ml/h) } \\
\hline $\begin{array}{l}\text { Range } \\
\text { Mean } \pm \text { S.D }\end{array}$ & $\begin{array}{c}(2.0-35.2) \\
8.7 \pm 7.0\end{array}$ & $\begin{array}{c}(3.4-16.0) \\
8.0 \pm 4.2\end{array}$ & $\begin{array}{c}(2.0-52.0) \\
9.2 \pm 8.0\end{array}$ & $\begin{array}{c}(3.1-18.0) \\
8.0 \pm 4.0\end{array}$ \\
\hline $\begin{array}{l}\text { Change \% } \\
\mathrm{P}<\end{array}$ & $\begin{array}{l}- \\
-\end{array}$ & $\begin{array}{l}-8 \\
\text { N.S }\end{array}$ & $\begin{array}{l}5.75 \\
\text { N.S }\end{array}$ & $\begin{array}{l}-8 \\
\text { N.S }\end{array}$ \\
\hline
\end{tabular}

- $\mathrm{n}=$ Number of cases

- N.S = Non significant 


\section{TABLE II}

Upper reference limits (URLs) for plasma norepinephrine, epinephrine, urinary vanillylmandelic acid, serum aldosterone, plasma renin activity and Aldo/PRA ratio in the control age groups.

\begin{tabular}{|l|c|c|c|c|c|c|}
\hline Age & $\begin{array}{c}\mathrm{NE} \\
(\mathrm{pg} / \mathrm{ml})\end{array}$ & $\begin{array}{c}\mathrm{E} \\
(\mathrm{pg} / \mathrm{ml})\end{array}$ & $\begin{array}{c}\text { U. VMA } \\
(\mathrm{mg} / 24 \mathrm{~h})\end{array}$ & $\begin{array}{c}\text { Aldo } \\
(\mathrm{ng} / \mathrm{dl})\end{array}$ & $\begin{array}{c}\text { PRA } \\
(\mathrm{ngA} 1 / \mathrm{ml} / \mathrm{h})\end{array}$ & $\begin{array}{c}\text { Aldo/PRA } \\
(\mathrm{ng} / \mathrm{dl} / \mathrm{ng} / \mathrm{ml} / \mathrm{h})\end{array}$ \\
\hline $5-10 \mathrm{yr}$ & 323.30 & 131 & 4.05 & 32.85 & 5.20 & 22.70 \\
\hline $11-15 \mathrm{yr}$ & 287 & 129.13 & 6.33 & 36.10 & 3.80 & 16.40 \\
\hline $16-40 \mathrm{yr}$ & 365 & 152.20 & 8.0 & 31.70 & 5.41 & 25.20 \\
\hline $41-60 \mathrm{yr}$ & 390 & 136.40 & 8.10 & 34.50 & 6.10 & 16.0 \\
\hline
\end{tabular}

-Upper reference limit of each parameter was calculated from its mean value $+2 \mathrm{SD}$.

-Shaded boxes denote the statistical insignificance $(\mathrm{P}>0.05)$ of the upper reference limit of a given parameter in the different age groups.

significantly elevated in children and then gradually decreased to its lowest value in older adults. The increase \% was 134.02, $105.86,76.79$ and $65(\mathrm{P}<0.001)$ in cases aged 5-10, 11-15, 16-40 and 41-60 yr, respectively. Aldo/PRA ratio was significantly decreased by $38 \% \quad(\mathrm{P}<0.01)$, $22.5 \%(\mathrm{P}<0.05)$ and $44.5 \%(\mathrm{P}<0.001)$ in hypertensive children, pubertals and adults, but was nonsignificantly changed in older hypertensives.

Table 4. shows the percent of elevation in the levels of plasma NE, E, UVMA, serum aldosterone, PRA and Aldo/PRA ratio above their respective URLs in all of the studied hypertensive age groups. In children, the prevalence of elevation in the foregoing parameters was $64 \%$ (16/25 cases), $72 \%$ (18/ $25)$ and $92 \%(23 / 25), 24 \%(6 / 25), 52 \%(13 /$ $25)$ and $0 \%(0 / 25)$, respectively. In adolescents, the elevation was recorded in $92 \%$ (23/25), 48\% (12/25), 80\% (20/25), $32 \%(8 / 25), 96 \%(24 / 25)$ and $4 \%(1 / 25)$, respectively. In young adults, the incidence $\%$ was 92 (23/25), 44 (12/25), 84 (21/25), 8 $(2 / 25), 52(13 / 25)$ and 0 , respectively. In older adults, the incidence \% was 92.3 (24/ 25), 84.6 (22/25), 76.9 (20/26), 0, 11.5 (3/ $26)$ and $3.8(1 / 26)$, respectively.
Fig.1-7 represent significant positive correlation coefficients between UVMA and SBP or DBP values $(\mathrm{r}=0.35, \mathrm{p}<0.05)$ in hypertensive children, UVMA and DBP in hypertensive adolescents $(\mathrm{r}=0.4, \mathrm{p}<0.05)$, serum aldosterone and SBP $(r=0.34$, $\mathrm{p}<0.05)$ or DBP values $(\mathrm{r}=0.33, \mathrm{p}<0.05)$ in older hypertensives, and PRA and SBP $(\mathrm{r}=0.42, \mathrm{p}<0.05)$ or DBP values $(\mathrm{r}=0.45$, $\mathrm{p}<0.05)$ in adult hypertensives

\section{DISCUSSION}

Much of the published reference range data for plasma catecholamines in healthy children are incomplete and often contradictory. Literature contains insufficient and often contradictory reference range data for plasma catecholamines and their urinary metabolites, particularly in adolescents and old adults. Many factors contribute to the large variation in published pediatric and adult reference ranges. There is no uniformity in the way results are reported from different laboratories. Published normal ranges vary greatly depending on the analytical method used, the number of selection criteria for the so-called healthy subjects and the statistical 
TABLE III

Changes in the studied biochemical parameters in the hypertensive cases compared to age - matched normal controls

\begin{tabular}{|c|c|c|c|c|c|c|c|}
\hline Age & $\begin{array}{l}\text { Groups } \\
(\mathrm{pg} / \mathrm{ml})\end{array}$ & $\begin{array}{c}\mathrm{NE} \\
(\mathrm{pg} / \mathrm{ml})\end{array}$ & $\begin{array}{c}\text { E } \\
(\mathrm{pg} / \mathrm{ml})\end{array}$ & $\begin{array}{l}\text { U.VMA } \\
\text { (mg/24h) }\end{array}$ & $\begin{array}{l}\text { Aldo } \\
\text { (ng/dl) }\end{array}$ & $\begin{array}{c}\text { PRA } \\
\text { (ng/ml/h) }\end{array}$ & Aldo/PRA \\
\hline $\begin{array}{l}\vec{\lambda} \\
\stackrel{0}{1} \\
i\end{array}$ & $\begin{array}{l}\text { Gr. Ia (N.C) } \\
\text { Mean } \pm \text { S.D } \\
\text { Gr.IIa (Hypertensive) } \\
\text { Mean } \pm \text { S.D } \\
\text { Change } \%\end{array}$ & $\begin{array}{l}231.60 \pm 50.36 \\
398.00 \pm 91.89^{c} \\
71.85\end{array}$ & $\begin{array}{l}90.68 \pm 20.10 \\
178.24 \pm 58.99^{c} \\
96.56\end{array}$ & $3.76 \pm 1.13$ & $\begin{array}{l}18.23 \pm 7.31 \\
\\
27.95 \pm 7.0^{c} \\
53.29\end{array}$ & $2.44 \pm 0.69$ & $8.7 \pm 7.0$ \\
\hline $\begin{array}{l}\text { 方 } \\
\stackrel{2}{1} \\
=\end{array}$ & $\begin{array}{l}\text { Gr. I b (N.C) } \\
\text { Mean } \pm \text { S.D } \\
\text { Gr. II b (Hypertensive) } \\
\text { Mean } \pm \text { S.D } \\
\text { Change \% }\end{array}$ & $\begin{array}{l}195.00 \pm 45.98 \\
477.16 \pm 179.49^{c} \\
144.7\end{array}$ & $\begin{array}{l}93.17 \pm 17.98 \\
148.56 \pm 67.18^{c} \\
59.45\end{array}$ & $\begin{array}{l}4.57 \pm 0.88 \\
7.08 \pm 1.34^{\mathrm{c}} \\
54.92\end{array}$ & $\begin{array}{l}23.03 \pm 6.52 \\
32.18 \pm 10.43^{c} \\
39.75\end{array}$ & $\begin{array}{l}3.07 \pm 1.07 \\
6.32 \pm 2.30^{c} \\
105.86\end{array}$ & $\begin{array}{l}8.0 \pm 4.2 \\
6.2 \pm 7.2^{a} \\
-22.5\end{array}$ \\
\hline 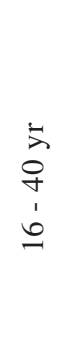 & $\begin{array}{l}\text { Gr. I c ( N.C ) } \\
\text { Mean } \pm \text { S.D } \\
\text { Gr. IIc (Hypertensive) } \\
\text { Mean } \pm \text { S.D } \\
\text { Change \% }\end{array}$ & $\begin{array}{l}234.15 \pm 65.31 \\
574.92 \pm 168.42^{\mathrm{c}} \\
145.53\end{array}$ & $\begin{array}{l}91.54 \pm 30.31 \\
150.00 \pm 76.12^{c} \\
63.86\end{array}$ & $\begin{array}{l}5.53 \pm 1.17 \\
9.97 \pm 3.28^{c} \\
80.29\end{array}$ & $\begin{array}{l}19.54 \pm 6.01 \\
5.86 \pm 8.32^{b} \\
32.33\end{array}$ & $\begin{array}{l}2.93 \pm 1.24 \\
5.18 \pm 1.46^{\mathrm{c}} \\
76.79\end{array}$ & $\begin{array}{l}9.2 \pm 8.0 \\
5.1 \pm 2.1^{\mathrm{c}} \\
-44.5\end{array}$ \\
\hline $\begin{array}{l}\grave{2} \\
8 \\
1 \\
7\end{array}$ & $\begin{array}{l}\text { Gr. I d (N.C) } \\
\qquad \text { Mean } \pm \text { S.D } \\
\text { Gr. IId (Hypertensive) } \\
\text { Mean } \pm \text { S.D } \\
\text { Change } \%\end{array}$ & $\begin{array}{l}565.31 \pm 152.84^{\mathrm{c}} \\
123.51\end{array}$ & $\begin{array}{l}180.65 \pm 46.06^{\mathrm{c}} \\
97.91\end{array}$ & $\begin{array}{l}9.86 \pm 1.77^{c} \\
59.55\end{array}$ & $\begin{array}{l}26.71 \pm 3.96^{\mathrm{c}} \\
25.71\end{array}$ & $\begin{array}{l}4.72 \pm 1.60^{\mathrm{c}} \\
65.0\end{array}$ & $\begin{array}{l}7.0 \pm 4.0 \\
-12.5\end{array}$ \\
\hline
\end{tabular}

$*_{\mathrm{a}}(\mathrm{p}<0.05), \mathrm{b}(\mathrm{p}<0.01), \mathrm{c}(\mathrm{p}<0.001)$ 


\section{TABLE IV}

The prevalence of elevated levels of plasma norepinephrine, epinephrine, urinary vanillylmandelic acid, serum aldosterone, plasma renin activity and Aldo/PRA ratio above their respective URLs in the different hypertensive age groups.

\begin{tabular}{lrrrrrr}
\hline Age & NE & E & UVMA & Aldo & PRA & Aldo/PRA \\
\hline $5-10 \mathrm{yr}$ & $64 \%$ & $72 \%$ & $92 \%$ & $24 \%$ & $52 \%$ & $0 \%$ \\
$11-15 \mathrm{yr}$ & $92 \%$ & $48 \%$ & $80 \%$ & $32 \%$ & $96 \%$ & $4 \%$ \\
$16-40 \mathrm{yr}$ & $92 \%$ & $44 \%$ & $84 \%$ & $8 \%$ & $52 \%$ & $0 \%$ \\
$41-60 \mathrm{yr}$ & $92.3 \%$ & $84.6 \%$ & $76.9 \%$ & $0 \%$ & $11.5 \%$ & $3.8 \%$ \\
\hline
\end{tabular}

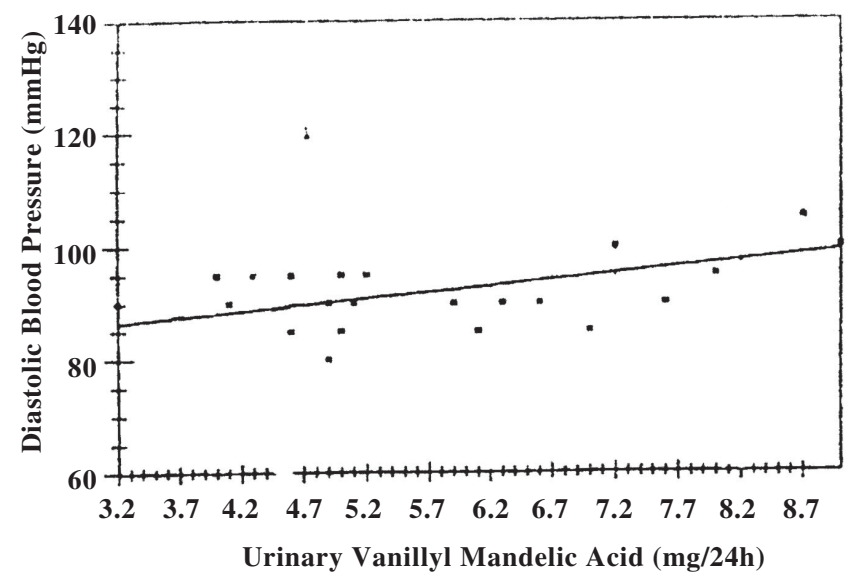

Figure 1. Correlation between urinary vanillylmandelic acid (VMA) and systolic blood pressure (SBP) levels in hypertensive children (aged 5-10y), $(r=0.35, p<0.05$, critical $r= \pm 0.34)$

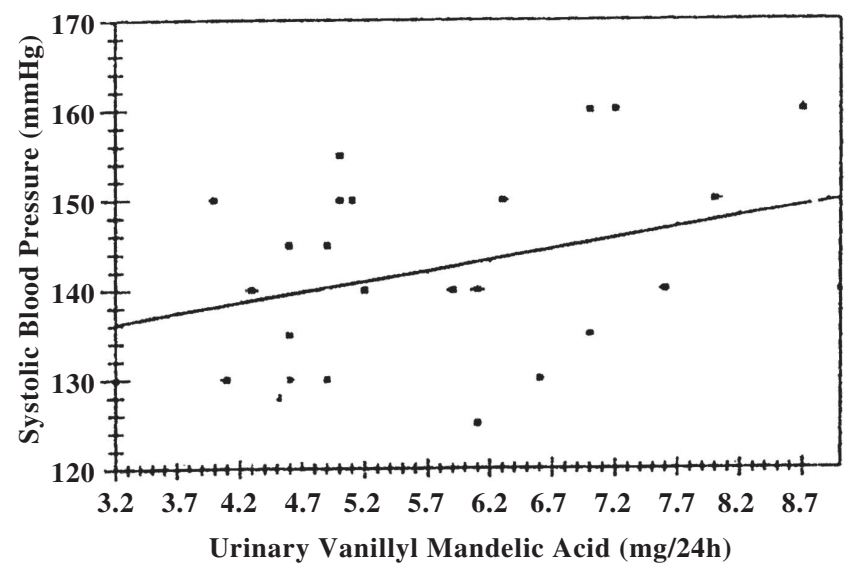

Figure 2. Correlation between urinary vanillylmandelic acid (VMA) and diastolic blood pressure (DBP) levels in hypertensive children (aged 5-10y), $(\mathrm{r}=0.35, \mathrm{p}<0.05$, critical $\mathrm{r}= \pm 0.34$ ) 


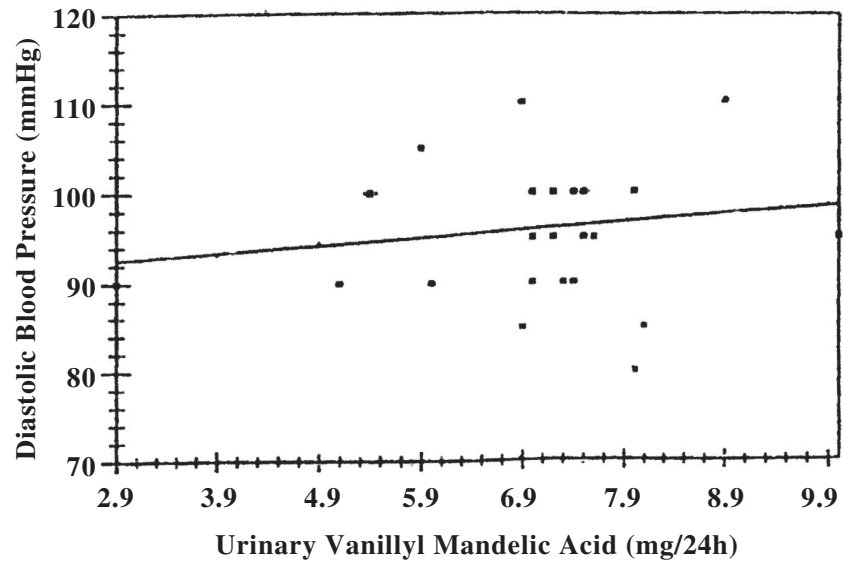

Figure 3. Correlation between urinary vanillylmandelic acid (VMA) and diastolic blood pressure (DBP) levels in hypertensive pubertals (aged 11-15y), $(\mathrm{r}=0.40, \mathrm{p}<0.05$, critical $\mathrm{r}= \pm 0.34$ )

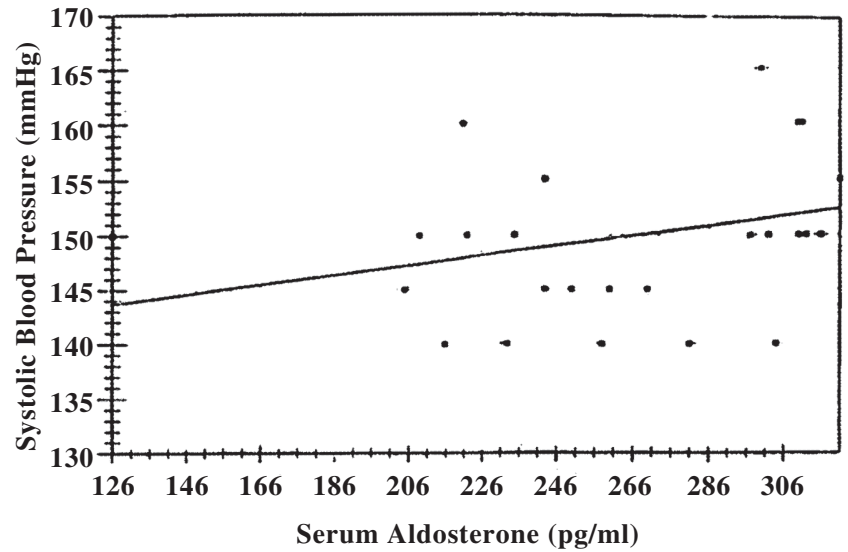

Figure 4. Correlation between serum aldosterone and systolic blood pressure (SBP) LEVELS IN OLD Hypertensives (aged 41-60 y), $(r=0.34, p<0.05$, critical $r= \pm 0.33)$

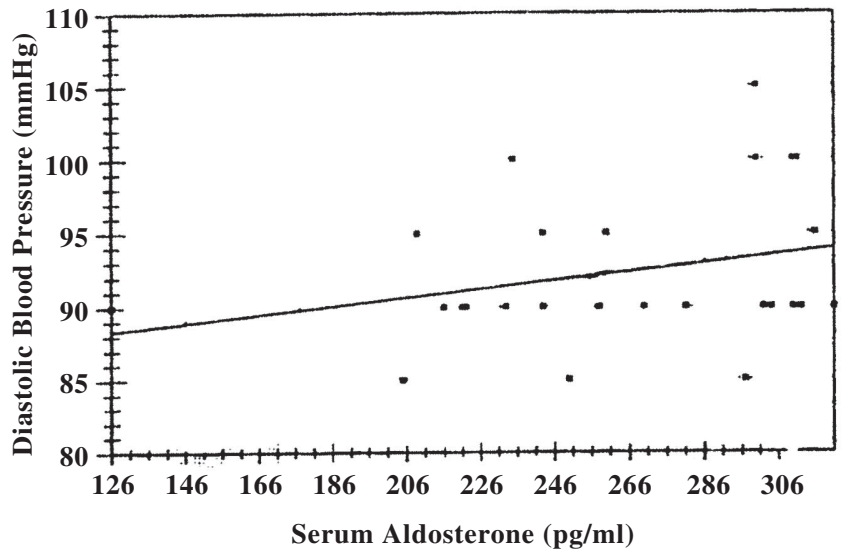

Figure 5. Correlation between serum aldosterone and diastolic blood pressure (DBP) levels in old hypertensives (aged 41-60 y), $(\mathrm{r}=0.33, \mathrm{p}<0.05$, critical $\mathrm{r}= \pm 0.33$ ) 


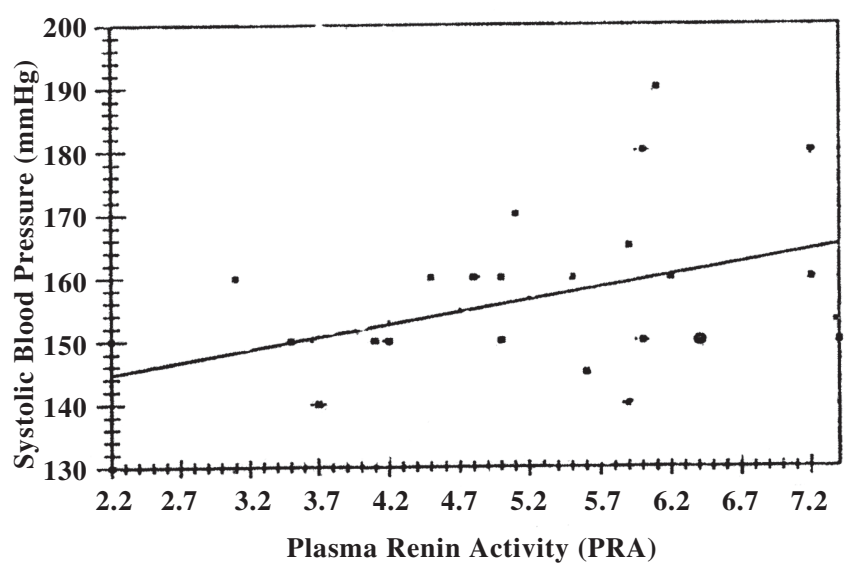

Figure 6. Correlation between plasma rennin activity (PRA) and systolic blood pressure (SBP) levels in adult hypertensives (aged $16-40 \mathrm{y}),(\mathrm{r}=0.42, \mathrm{p}<0.05$, critical $\mathrm{r}= \pm 0.34$ )

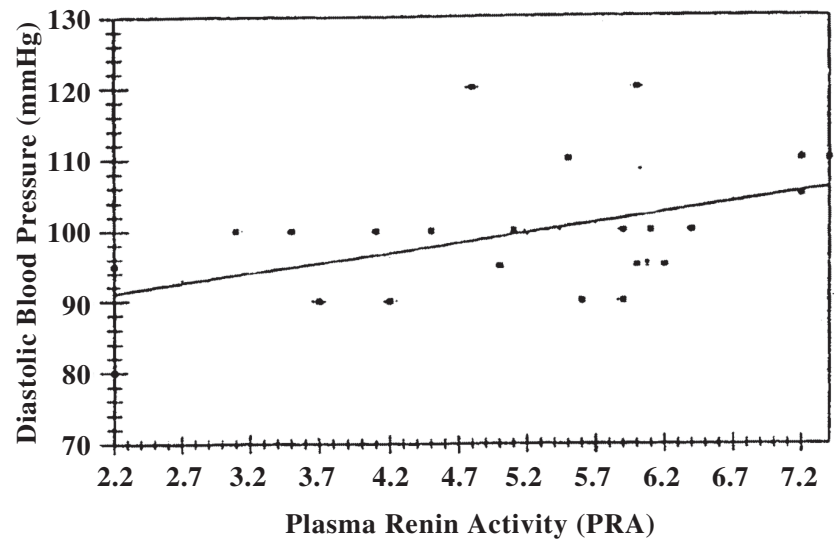

Figure 7. Correlation between plasma renin activity (PRA) and diastolic blood pressure (DBP) levels in adult hypertensives (aged 16-40 y) $(r=0.45, \mathrm{p}<0.05$, critical $\mathrm{r}= \pm 0.34)$

methods employed (Bondi et al., 1999). This pilot study is the first of a kind, to the best of our knowledge, which used a wide range of age $(5-60 \mathrm{yr})$ to investigate the effect of age on the levels of plasma catecholamines and urinary VMA, and to establish their URLs in Egyptian healthy normotensive children, pubertals and adults. Radioimmunoassay and HPLC are certainly the most common methods for measurement of plasma catecholamines and the reported precision of the RIA procedure seems acceptable and has the capability of good accuracy and sensitivity (Hjemdahl,1984 and Kaplan,1987). In the present study the RIA procedure was implemented for determination of plasma catecholamine concentrations due to its feasibility and availability in the medical centers and hospitals, whereas HPLC technique is highly expensive, restricted to research centers and universities and needs experienced personnel.

Results obtained from this study (Table 1) indicate that resting plasma $\mathrm{NE}$ concentration is nonsignificantly affected by age in normotensive subjects except for adolescents, in which a slightly significant reduction is recorded, compared to the lowest control age group (5-10 yr). On the other hand, plasma $\mathrm{E}$ level is not 
significantly changed by age. Parallel results have been previously reported regarding the unchanged resting plasma $E$ level by age in adult normotensives using HPLC (Kaplan,1987). However, Brown et al. (1996) reported that resting plasma NE level increases significantly with age among adult normotensive subjects (21-70 yr) using isocratic HPLC. According to our results, only one upper reference limit (URL) for plasma E level is reported averaging 137.15 $\mathrm{pg} / \mathrm{ml}$ at all ages. As regards to plasma NE level an average URL of $362.26 \mathrm{pg} / \mathrm{ml}$ is reported for normotensive children, young adults and older subjects, with the exception of adolescents, who have URL of $287 \mathrm{pg} / \mathrm{ml}$. (Table 2).

Data presented in Table (3) demonstrate that the resting plasma $\mathrm{NE}$ and $\mathrm{E}$ levels are significantly elevated in all studied hypertensive groups, compared to their agematched controls, and that the most notable increase is observed in the plasma NE level. The average percent of hypertensive cases in all studied age groups with elevated plasma NE and E levels above the URLs are 85.10 and $62.15 \%$, respectively. This suggests the higher sensitivity of the plasma NE than E level to elevation in the blood pressure, and supports the viewpoint that the plasma NE and $\mathrm{E}$ are not necessarily inducers but are more likely common sequelae of essential hypertension. This suggestion is confirmed by the insignificant correlation coefficients ( $r$-values) between resting plasma $\mathrm{NE}$ and $\mathrm{E}$ levels and resting SBP and DBP values (figures not shown). Our results are in agreement with Jindra et al. (1990) and Braun et al. (1994), who reported no significant relationships between resting blood pressure values and catecholamine levels using HPLC. Jablonskis and Howe (1995) attributed the elevation in plasma $\mathrm{E}$ level to hypertension. They reported that the vasodilatory and glycaemic properties of circulating $\mathrm{E}$ are important in maintaining blood flow and energy supply to skeletal muscles, therefore, it is conceivable that $\mathrm{E}$ is secreted in hypertensive patients to counteract the resultant vasoconstriction and to maintain blood flow in peripheral vascular system. Jacobs et al. (1997) attributed the significant elevation in plasma $E$ level in hypertensive adults $(38.1 \pm 6.7 \mathrm{yr})$ to a higher total body $\mathrm{E}$ spillover rate in the hypertensive subjects than in the normotensives and not to a decreased plasma clearance of $E$. It has been proposed that a brief increase in plasma E concentration results in the uptake of $\mathrm{E}$ into the sympathetic nerve terminals. Subsequent release of $E$ stimulates presynaptic beta-adrenergic receptors resulting in a prolonged increase in plasma $\mathrm{NE}$ concentration, with amplified sympathetic responses and vasoconstriction (Stein et al., 1997).

A significant age-dependent elevation in 24 h UVMA excretion was observed which peaked in the older normotensives (Table 1). Thus, three age-dependent URLs are reported for UVMA concentration, which are 4.05 for children, 6.33 for adolescents and $8.0 \mathrm{mg} / 24 \mathrm{~h}$ for adults (16-60 yr) (Table 2). Our results are similar to those of Stein et al., (1997), who reported that the increase in UVMA concentration measured by HPLC is age-dependent, and the URLs are 3.5 for children (5-9 yr), 7.7 for adolescents (10-19 $\mathrm{yr}$ ) and $8.1 \mathrm{mg} / 24 \mathrm{~h}$ for adults (> $19 \mathrm{yr}$ ). In case of hypertensive subjects, UVMA concentration is significantly elevated in all studied age groups, and is more pronounced in children, compared to their age - matched controls (Table 3). The prevalence of elevated UVMA levels above the URLs is recorded in $92 \%$ of children, in $80 \%$ of adolescents, in $84 \%$ of adults and in $76.9 \%$ of older hypertensives (Table 4). In general, the average percent of hypertensive cases at all ages with increased UVMA levels above their respective URLs is $83.2 \%$. In this study three statistically significant positive correlation coefficients are reported between UVMA and SBP or DBP values in hypertensive children, and between UVMA and DBP value in hypertensive adolescents (Fig.1-3). Our findings indicate that UVMA is well correlated with essential hypertension particularly in children and adolescents.

In the course of the present study serum aldosterone, PRA and their ratio were determined to screen for pimary hyperaldosteronism among the selected normokalemic essential hypertensives. 
None of the aforementioned parameters was found to be significantly changed by age in normotensives compared to the lowest control age group (5-10 yr), with the exception of serum aldosterone concentration and PRA which manifested slightly significant elevations in normotensive adolescents (Table 1). Accordingly, an average URL of $33 \mathrm{ng} / \mathrm{dl}$ for serum aldosterone is reported for children and adults (16-60 yr) and a higher URL of $36.10 \mathrm{ng} / \mathrm{dl}$ for adolescents. On the other hand, an average URL of $5.29 \mathrm{ng} / \mathrm{ml} /$ $\mathrm{h}$ for PRA by RIA is reported for children and adults, a lesser URL of $3.8 \mathrm{ng} / \mathrm{ml} / \mathrm{h}$ for adolescents, and of $6.1 \mathrm{ng} / \mathrm{ml} / \mathrm{h}$ for older subjects. As to Aldo / PRA ratio a single URL of 20 is reported for all ages (Table $2)$. Our results are in line with previously reported URLs; 35, 48 and $30 \mathrm{ng} / \mathrm{dl}$ for serum aldosterone in children, adolescents and adults, respectively (Lawrence \& Ronald,1987) and $4.8 \mathrm{ng} / \mathrm{ml} / \mathrm{h}$ for PRA in adults (Greenspan \& Baxter, 1987). Comparison of all normokalemic hypertensive groups to their age-matched controls showed a significant elevation in serum aldosterone level, and a more pronounced increase in PRA with a concomitant significant reduction in Aldo/ PRA ratio except for older hypertensives group in which Aldo/PRA ratio remains unchanged (Table 3). Comparable results were previously reported regarding adult hypertensives (Goodfriend et al., 1995). Inconsistent results were reported by Brown et al.(1996), who reported that serum aldosterone and PRA do not differ significantly in hypertensive subjects. This discrepancy may be due to the short three day - washout period without antihypertensives prior to blood collection. Some antihypertensives, such as long acting ACE inhibitors, or amlodipine may still be exerting some effect on the reninangiotensin system. It is worthwhile to point out that the most notable increase in serum aldosterone level and PRA was recorded in the lowest age group, which then tends to decrease gradually reaching the lowest increase in the older hypertensives. In the present study, two significant positive correlation coefficients are reported between serum aldosterone and SBP or DBP values in older hypertensives (41-60 yr.) (Fig.4-5). Also, two significant positive correlation coefficients are reported between PRA and SBP or DBP values in adult hypertensives (16-40 yr.) (Fig. 6-7). Our results are in agreement with those of Goodfriend et al. (1995), who reported significant positive correlations between serum aldosterone and SBP or $\mathrm{DBP}$ in hypertensive subjects (SBP/ $\mathrm{DBP} \geq 140 / 190$ ) aged $>23 \mathrm{yr}$. According to our findings, the prevalence of elevated Aldo/PRA ratio above its URL is recorded only in 4 and $3.8 \%$ of hypertensive adolescents and older subjects, respectively, however, no cases of primary hyperaldosteronism are identified among the different hypertensive groups (Table 4). It is reported that Aldo/PRA ratio should exceed 20 (Koay et al., 2000) or 25 (Fardella et al., 2000) to identify cases with primary hyperaldosteronism. In previous studies Marin et al. (1994) recorded primary hyperaldosteronism in only $0.7 \%$ of 3500 hypertensive cases, while Anderson et al. (1994) and Gordon et al. (1994) recorded an incidence of 1.4 and $8.5 \%$ of primary hyperaldosteronism, respectively, among their studied hypertensive cases. Of the possible explanations for the zero \% incidence of primary hyperaldosteronism among uncomplicated essential hypertensive subjects included in this study (Table 4) might be the relatively small number of cases and the lower hypertension compared to other studies.

\section{CONCLUSIONS}

Results obtained from this pilot study revealed several conclusions: 1Establishment of age-dependent upper reference limits is necessary for plasma NE, UVMA, serum aldosterone and PRA levels, while a single URL encompassing all ages for plasma E level is satisfactory. 2Uncomplicated essential hypertension is associated with a more pronounced elevation in the plasma NE level than that of plasma $\mathrm{E}$ especially in hypertensive adolescents and adults, whereas in children 
and older subjects both of plasma NE and E levels are equally affected. 3-The lack of significant correlations between plasma free catecholamines and SBP or DBP in the essential hypertensives at all ages indicates the individual variations in the catecholamines response to the degree of hypertension, yet the high prevalence of elevated NE and E levels among the hypertensive subjects confirms the suggestion that they are a common consequence rather than playing a role in the pathogenesis of essential hypertension. 4-The prevalence of primary hyperaldosteronism is $0 \%$ among the selected uncomplicated normokalemic essential hypertensives.

\section{REFERENCES}

ANDERSON GH, BLAKEMAN N, STREETEN DHP (1994) The effect of age on prevalence of secondary forms of hypertension in 4429 consecutively referred patients. J Hypertension 12: $609-615$.

BONDI M, GRUGNI G, VELARDO A, BIELLA O, VENNERI MG, MORABITO F, MENOZZI R, DELRIO G (1999) Adrenomedullary response to caffeine in pubertal and pubertal obese subjects. Inter $\mathbf{J}$ Obesity 23: 992 - 996

BRAUN LT, POTEMPA K, HOLM K, FOGG L, SZIDON $P$ (1994) The role of catecholamines, age and fitness on blood pressure reactivity to dynamic exercise in patients with essential hypertension. Heart Lung 23 (5): $404-412$.

BROWN MA, CRAMP HA, ZAMMIT VC, WHITWORTH JA (1996) Primary hyperaldosteronism: A missed diagnosis in essential hypertensives? Aust NZ J Med 26: 533 - 538.

DOSH SA (2001) The diagnosis of essential and secondary hypertension in adults. J Fam Pract 50: 707-712.

FARDELLA CE, MOSSO L, GOMEZ SC, CORTES P, SOTO J, GOMEZ L, PINTO M, HUETE A, OESTREICHER E, FORADORI A, MONTERO J (2000) Primary hyperaldosteronism in essential hypertensives: Prevalence, biochemical profile, and molecular biology. J Clin Endocrinol Metab 85 (5): $1863-1867$.

GOODFRIEND TL, EGAN B, STEPNIAKOWSKI K, BALL DL (1995) Relationships among plasma aldosterone, high - density lipoprotein cholesterol, and insulin in humans. Hypertension 25 (1): 30 - 36.

GORDON RD, STOWASSER M, TUNNY J (1991) Clinical and pathological diversity of primary hyperaldosteronism including a new family variety.Clin Exper Pharmacol Physiol 18:283-286.

GORDON RD, KLEMM SA, TUNNY TJ, STOWASSER M (1992) Primary aldosteronism: hypertension with a genetic basis. Lancet 340:159-161.

GORDON R. (1993) Primary aldosteronism: A new understanding. Med J Aust 158: 729 - 31.
GORDON RD, STOWASSER M, KLEMM SA, TUNNY TJ (1994) Primary aldosteronism and other forms of mineralocorticoid hypertension. In: SWALES JD (ed). Textbook of Hypertension, Oxford, Blackwell Scientific Publications, pp. 865 - 892.

GORDON RD, STOWASSER M, KLEMM SA, TUNNY TJ (1995) Primary aldosteronism-some genetic,morphological and biochemical aspects of subtypes. Steroids 60:35-41.

GREENSPAN FS, BAXTER JD (1987) Adrenal medulla. In: Basic and Clinical Endocrinology, $4^{\text {th }}$ edn, chapter 8, California, Appleton \& Lange Medical Book, pp. $371-373,378,379$.

HIRAMATSU K, YAMADA T, YUKIMURA Y (1981) A screening test to identify aldosterone-producing adenoma by measuring plasma renin activity. Arch Intern Med 141:1589-1593.

HJEMDAL P (1984) Interlaboratory comparison of plasma catecholamine determinations using several different assays. Acta Physiol Scand 527:43-54.

JABLONSKIS LT, HOWE PR (1995) Plasma adrenaline responses to long term modification of blood pressure in normotensive rats and hypertensive rats. J Hypertension 13 (3): 319 - 32.

JACOBS MC, LENDERS JW, WILLEMSEN JJ, THIEN T (1997) Adrenomedullary secretion of epinephrine is increased in mild essential hypertension. Hypertension 29 (6): 1303 - 308.

JINDRA A, SALIKOVA J, BULTAS J (1990) Relationship between plasma catecholamines and the reninaldosterone system during exercise in normal and essential hypertensive subjects. Clin Exper Hypertension 12: 415-435.

KAPLAN LA (1987) Catecholamines. In: Methods in clinical chemistry, chapter 124, Philadelphia, WB Saunders Company, p. 948.

KOAY ES, LOH KC, KHAW MC, EMMANUEL SC, YOUNG WF (2000) Prevalence of primary aldosteronism among Asian hypertensive patients in Singapore. J Clin Endocrinol Metab 85:2854-2859.

LAWRENCE MD, RONALD JW (1987) Function of the adrenal cortex. In: Clinical chemistry, $3^{\text {rd }}$ edn., Chapter 43, Vol. 3, Sydney, WB Saunders Company, pp. 1564, 156.

MCKENNA TJ, SEQUEIRA ST, HEFFMAN A (1991) Diagnosis under random conditions of all disorders of the renin-angiotensin-aldosterone axis, including primary hyperaldosteronism J Clin Endocrinol Metab 73: 952-957.

MARIN M, GÓMEZ R, GONZÁLES BJ, ESPER R, BAGLIVO H (1994) Primary aldosteronism. High incidence of idiopathic hyper-aldosteronism (Abstr). Proceedings of $15^{\text {th }}$ Scientific Meeting of The International Society of Hypertension, p. 163.

MURRAY RS (1982) Schaum's Outline Series of Theory and Problems of probability and Statistics,McGrawHill Book Company, Singapore.

RIBEIRO MO, ANTUNES E, NUCCI DE, LOVISOLO SM, ZATZ R (1992) Chronic inhibition of nitric oxide synthesis. A new model of arterial hypertension. Hypertension 20: 298 - 303.

SMYTHE GA, EDWARDS G, GRAHAM P, LAZARUS L (1992) Biochemical diagnosis of phaeochromocytoma by simultaneous measurement of urinary excretion of epinephrine and norepinephrine. Clin Chem 38: 486 - 92.

STEIN CM, NELSON R, WOOD M, WOOD AJ (1997) Nore-pinephrine release in the human forearm: Effects of epinephrine. Hypertension 30: 1078 - 1084.

WYBENGA D, PILEGGI VJ (1967) Quantitative determination of 3-methoxy-4-hydroxymandellic acid (VMA) in urine. Clin Chim Acta 16: 147-154. 